\title{
Simulation Studies on Ethanol Production from Sugar Cane Residues
}

DOI:

10.1021/acs.iecr.5b04500

\section{Document Version}

Accepted author manuscript

Link to publication record in Manchester Research Explorer

\section{Citation for published version (APA):}

Michailos, S., Parker, D., \& Webb, C. (2016). Simulation Studies on Ethanol Production from Sugar Cane Residues. Industrial and Engineering Chemistry Research, 55(18), 5173-5179.

https://doi.org/10.1021/acs.iecr.5b04500

\section{Published in:}

Industrial and Engineering Chemistry Research

\section{Citing this paper}

Please note that where the full-text provided on Manchester Research Explorer is the Author Accepted Manuscript or Proof version this may differ from the final Published version. If citing, it is advised that you check and use the publisher's definitive version.

\section{General rights}

Copyright and moral rights for the publications made accessible in the Research Explorer are retained by the authors and/or other copyright owners and it is a condition of accessing publications that users recognise and abide by the legal requirements associated with these rights.

\section{Takedown policy}

If you believe that this document breaches copyright please refer to the University of Manchester's Takedown Procedures [http://man.ac.uk/04Y6Bo] or contact uml.scholarlycommunications@manchester.ac.uk providing relevant details, so we can investigate your claim.

\section{OPEN ACCESS}




\title{
Simulation studies on ethanol production from
}

\section{sugar cane residues}

Stavros Michailos, ${ }^{\dagger}$ David Parker ${ }^{\ddagger}$ and Colin Webb* ${ }^{*} \dagger$

${ }^{\dagger}$ School of Chemical Engineering and Analytical Science, The University of Manchester, Oxford Road, Manchester M13 9PL, United Kingdom, and ${ }^{\ddagger}$ School of Biosciences, University of Exeter, Stocker Road, Exeter, EX4 4QD, United Kingdom

\begin{abstract}
Ethanol is generally considered to be a renewable energy source and is in principle a greener alternative to conventional fossil fuels. During the last few decades production of ethanol on a large scale has achieved remarkable escalation mainly due to its flexible application and high demand. Nevertheless robust technologies are yet to be established focusing on the exploitation of lignocellulosic material and waste. Sugar cane processes for ethanol or sugar production provide as waste bagasse - approximately 250-280 $\mathrm{kg}$ of bagasse per ton of sugar cane. This solid residue of the cane milling process has, in most cases, been misused so far. If it is not disposed to land, it is either sold as animal feed or used in a rather inefficient way to cover the domestic energy needs of the local residents. Thus the proper exploitation of bagasse will enhance the sustainability of existing biorefineries and give an important economic boost to local communities.
\end{abstract}

\section{INTRODUCTION}

Production of bio-based fuels from non-finite sources is crucial for meeting increasing world demand for transportation fuels and an essential element of the long term energy mix.

Research on biomass conversion routes derives from the very true fact that, technically, 
biofuels are able to replace oil derived fuels in all types of transportation, including as well aviation and ship fuels, most of which cannot be motorised by other renewable sources within the foreseeable future. Nevertheless significant and vital scientific and technical innovations are still needed in order to establish a commercially feasible and environmentally secure biomass sector, consisting of proper utilization of available feedstocks, enrichments in terms of production design and quality of the final product and development of a reliable supply chain ${ }^{1}$. Fermentation is a biochemical procedure in which sugars such as glucose, fructose, xylose, arabinose and sucrose are converted into alcohols, acids or gases. This metabolic process encompasses the utilisation of microorganisms such as yeast, bacteria and filamentous fungi. Lignocellulosic biomass primarily comprises of cellulose, hemicellulose and lignin. Sugars are derived from cellulose (a polymer of glucose) and hemicellulose (a polymer of xylose) material while lignin can be exploited in a steam cycle ${ }^{\mathbf{2 , 3}}$. Key stages involved in this process can be categorised as follows ${ }^{4}$ :

1. Pre-treatment and hemicellulose hydrolysis to pentoses $\left(\mathrm{C}_{5}\right)$ sugars.

2. Detoxification of hydrolysates through over liming

3. Cellulose hydrolysis to obtain hexoses $\left(\mathrm{C}_{6}\right)$ sugars.

4. Fermentation of sugars to alcohols.

5. Recovery of anhydrous ethanol.

6. Exploitation of lignin in a steam turbine cycle

The usage of ethanol as a fuel in conventional motor engines, either alone or as an additive to gasoline, has received notable consideration typically due to its potential environmental benefits over petroleum fuel. Anhydrous ethanol is usually blended with gasoline in various ratios so as to decrease the consumption of fossil fuels, along with reducing atmospheric contamination. The main drawback of ethanol compared to other fuels is its moderately low 
heating value. Production of cellulosic ethanol has received noteworthy attention during recent years. Sugar cane milling generates significant amounts of bagasse residue, a lignocellulosic material that can potentially be used as feedstock for biofuels production. This study explores the feasibility of several bagasse to ethanol routes by comparing possible alternatives at various steps within the process. Different approaches have been proposed for the biochemical conversion route (Figure 1) mainly related to alternative pre-treatment and fermentation sections. In this study liquid hot water (LHW) and dilute acid pre-treatments were investigated since, apart from breaking down the lignin structure, conversion of hemicellulose to $\mathrm{C}_{5}$ sugars is also achieved. The main trends in the fermentation section can be classified based on whether hydrolysis and fermentation take place in a single operation or separately and whether $\mathrm{C}_{5}$ and $\mathrm{C}_{6}$ sugars are co-fermented or not. In particular, the efficiency of separate hydrolysis with (SHcF) and without (SHF) (co-)fermentation, simultaneous saccharification with (SScF) and without (SSF) (co-)fermentation and continuous fermentation pathways have been tested and compared. Furthermore the profitability of onsite production of enzymes has been examined.

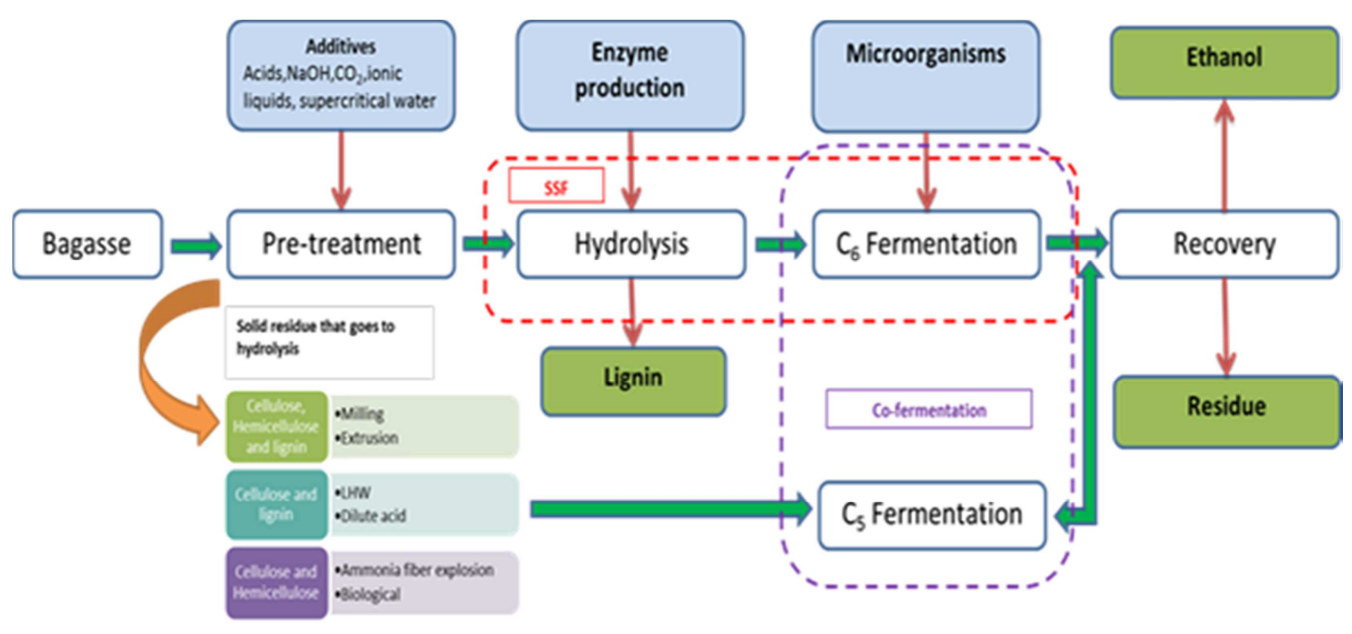

Figure 1. Bagasse biochemical conversion route 


\section{METHODOLOGY}

A comparative thermodynamic and economic evaluation of bagasse to cellulosic ethanol route alternatives has been undertaken. Initially material and energy balances have been established, valuation of the energetic performance of each process has then been carried out and finally economic models have been developed for conducting financial analysis. Thermodynamic analysis was performed by calculating the energy efficiency of the investigated alternatives. Energy efficiency can be defined as the ratio of the useful energy output of a process over the energy input. For each pathway a base case scenario has been developed using SuperPro Designer (SPD) to execute material and energy balances and Matlab for modelling the reactor kinetics. The reactor models have been transferred from Matlab to the simulator process models via VBA Excel Macro. Inlet bagasse flow rate for all the cases was set equal to $100 \mathrm{t} / \mathrm{h}$. Where necessary, models have been validated with real data by minimizing the sum of squared errors between experimental and computed values. For this purpose, an optimization routine based on genetic algorithm principles followed by a gradient based method (SQP - fmincon nested function in Matlab) has been developed in Matlab. Finally the code calculates the extent of the reactions and transfers values to SPD. Bagasse chemical composition is depicted in Table $\mathbf{1}$ and it was assumed that cellulose and hemicellulose consist only of glucan and xylan respectively. 


\section{Table 1. Typical bagasse chemical composition ${ }^{5}$}

\begin{tabular}{lc}
\hline Component & Dry Weight (\%) \\
\hline Cellulose (of which glucan = 100\%) & 45 \\
Hemicellulose (of which xylan =100\%) & 25 \\
Lignin & 20 \\
Extractives & 6.8 \\
Ash & 3.2 \\
\hline
\end{tabular}

\section{PREREATMENT SECTION}

Hydrolysis of hemicellulose occurs by engaging several methods such as acid $\left(\mathrm{HCl}, \mathrm{H}_{2} \mathrm{SO}_{4}\right)$, steam explosion, $\mathrm{CO}_{2}$ explosion, thermal, enzymatic, alkaline, organic solvents and hot liquid water. The main goal is to break down the lignin structure to render the holocellulose accessible to the enzymes ${ }^{6}$. Recent developments have proposed the employment of hydrogen peroxide $^{7}$ as an alternative impregnating agent for steam pretreatment (it can potentially endorse cellulose hydrolysis utilizing lower amount of enzymes) and ionic liquid ${ }^{8}$ pretreatment enhanced with a low concentration acid catalyst to promote the removal of both xylan and lignin. These approaches are, however, still at lab scale and their kinetics have not yet been studied exhaustively. In this study, two different pretreatment methods were explored and tested. The two candidates are liquid hot water (LHW) - a promising technology but yet to be established on an industrial basis and dilute acid (the most conventional method nowadays) with $\mathrm{H}_{2} \mathrm{SO}_{4}$ solution ( $\left.2 \% \mathrm{w} / \mathrm{w}\right)$. The kinetic models have been adapted from relevant literature ${ }^{9,10}$ and based on these the technoeconomic analysis of 
the pretreatment section was carried out. The reaction scheme of these kinetic models assumes that xylan is degraded to xylose which in sequence is decomposed to degradation products (only furfural was taken into consideration). The LHW process takes place in a plug-flow reactor while the dilute acid uses a Batch Stirred reactor. Xylose can be recovered from both processes at high yields. Table 2 illustrates the main outcomes of the two processes. Dilute acid attains higher conversion of hemicellulose compared to LHW, but produces acid inhibitors making the addition of one more step (neutralization) essential. On the other hand the energy consumption linked with LHW increases the overall cost of the process leading to the conclusion that the dilute acid method is more attractive than LHW. Hemicellulose hydrolysates have to be detoxified mainly from the sulfuric acid which is partially eliminated after reacting with ammonia and $\mathrm{Ca}(\mathrm{OH})_{2}$. The gypsum produced in this treatment is separated via a solid liquid separator.

Table 2. Comparison between LHW and dilute acid methods

\begin{tabular}{lcc}
\hline & Dilute Acid & LHW \\
\hline Xylose recovery [\%] & 85.2 & 82.8 \\
Total Reactor volume $\left[\mathbf{m}^{\mathbf{3}}\right.$ ] & 80 & 31 \\
Power demand [MWh/year] & 220,000 & 922,000 \\
Heating demand [MWh/year] & 28,000 & 320,000 \\
Cooling demand [MWh/year] & 24,000 & 20,000 \\
Energy Efficiency [\%] & 88 & 71 \\
ACC* [£/year] & 180,000 & 55,000 \\
Operating Cost [£/year] & $1,300,000$ & $5,800,000$ \\
\hline * Annualised Capital Cost = Equipment & Cost $\times \frac{i \times(1+i)^{n}}{-1+(1+i)^{n}}$, where $n$ the project lifetime in \\
\hline years and $i$ the discount rate
\end{tabular}




\section{CELLULOSE HYDROLYSIS}

Hydrolysis of cellulose to $\mathrm{C}_{6}$ sugars can be catalysed either by acids or enzymes.

Undoubtedly enzymatic hydrolysis is the dominant one due to high sugar yields, low operating costs and avoidance of inhibitors production. The main products of enzymatic hydrolysis of cellulose are glucose and cellobiose and it takes place under mild conditions; temperature of $50^{\circ} \mathrm{C}$ and $\mathrm{pH}$ of 5 . In spite of the above-mentioned advantages, enzymatic

hydrolysis is yet to achieve commercial success due to high enzyme costs ${ }^{\mathbf{1 1}}$. The participating reactions can be summarized as follows:

Cellulose + Water $\rightarrow$ Glucose

Cellulose + Water $\rightarrow$ Cellobiose

Cellobiose + Water $\rightarrow$ Glucose

The molecular formula of cellulose $\left(\mathrm{C}_{6} \mathrm{H}_{10} \mathrm{O}_{5}\right)_{n}$ was found in a component database developed by the National Renewable Energy Laboratory (NREL) ${ }^{\mathbf{1 2}}$. The kinetic model

developed by Peri et al. ${ }^{\mathbf{1 3}}$ has been used in this study and the kinetic parameters determined by fitting the model to experimental data ${ }^{5}$. The temperature was set to $50^{\circ} \mathrm{C}$ and the enzyme concentration to $3.22 \mathrm{~g} / \mathrm{L}$.

\section{ENZYMES PRODUCTION}

At this point the cost of producing hydrolytic enzymes on-site will be examined and compared with the commercial price. Cellulases are produced aerobically, via submerged fermentation, using the fungus Trichoderma reesei growing directly on the bagasse and recovered via vacuum and ultra-filtration. Trichoderma harzianum could also provide a feasible alternative for cellulase and xylanase production, in a short culture time, but the 
glucose yields from cellulose hydrolysis are quite $\operatorname{low}^{\mathbf{1 4}}(\sim 60 \%)$. Despite the fact, that recent studies have shown that enzymes can be produced at lower costs from solid state fermentation of Aspergillus niger strains ${ }^{\mathbf{1 5}}$, in this study the design of the enzyme production step was based on a report published by the NREL, due to its sufficient kinetic data ${ }^{\mathbf{1 6}} . T$ reesei fungus is cultivated aerobically on glucose in three in series bio-reactors in a media consisting of corn liquor, ammonium sulphate, magnesium sulphate, calcium chloride, potassium dihydrogen phosphate and ammonium hydroxide. The broth of the seed bioreactors is sent to the main the fermentor where cellulases are aerobically produced using this time as substrate cellulose. The process was designed on the basis that $20 \mathrm{mg}$ of cellulase can hydrolyse $1 \mathrm{~g}$ of cellulose. In our case we need to produce $385 \mathrm{~kg} / \mathrm{h}$ of cellulase. Table 3 presents the key process data, both technical and financial. The production cost of cellulase was found to be $£ 0.12$ per litre of ethanol produced which is much higher than the commercial price $\left(=0.017 £ / \mathrm{L}_{\text {of }} \mathrm{EtOH}^{17}\right)$. Therefore on-site production would not, currently, appear to be competitive.

\section{Table 3. Enzymes production economic data}

\begin{tabular}{lcccc}
\hline Utilities and capital cost & Size & Units per year & Price per unit ${ }^{16}[\mathfrak{f}]$ & $\begin{array}{c}\text { Cost } \\
{[\mathfrak{f} / \text { year }]}\end{array}$ \\
\hline Electricity & $16,680,000$ & $\mathrm{kWh}$ & 0.07 & $1,200,000$ \\
Steam & $49,360,000$ & $\mathrm{kWh}$ & 0.018 & 900,000 \\
Cooling water & $33,200,000$ & $\mathrm{kWh}$ & 0.0009 & 30,000 \\
Chilled water & $343,000,000$ & $\mathrm{~kg}$ & 0.0004 & $1,300,000$ \\
Labour & 161,000 & $\mathrm{~L}-$ hours & 15 & $2,400,000$ \\
Glucose & $3,360,000$ & $\mathrm{~kg}$ & 0.42 & $1,400,000$ \\
Nutrients & $5,976,000$ & $\mathrm{~kg}$ & 0.6 & $3,600,00$ \\
Corn Liquor & $3,488,000$ & $\mathrm{~kg}$ & 0.0417 & 146,000 \\
\hline \multicolumn{5}{c}{ Total Operating costs } \\
\hline
\end{tabular}




\section{FERMENTATION SECTION}

Mass balances for SHF and SHcF are expressed by Equations 4-7. In the case of co-fermentation, the substrate is a mixture of glucose and xylose. Growth rate $\mu$ is defined by a modified Monod model, while the Luedking-Piret model has been used to determine ethanol production rate and for substrate consumption an overall carbon balance has been implemented. Also, inhibition effects of acetic acid and furfural are included and expressed by exponential terms. Kinetic models for SSF and SScF were developed by combining SHF and SHcF models with the hydrolysis one (an inhibition term for ethanol on cellulose degradation was added). The values of the kinetic parameters were estimated by fitting the models to published experimental data ${ }^{\mathbf{1 8 , 1 9 , 2 0}}$.

$$
\begin{aligned}
& \frac{\mathrm{d} S}{\mathrm{dt}}=-\frac{1}{\mathrm{Yps}} * \frac{\mathrm{dP}}{\mathrm{dt}}-\frac{1}{\mathrm{Yxs}} * \frac{\mathrm{dX}}{\mathrm{dt}}-\mathrm{mX} \\
& \frac{\mathrm{dX}}{\mathrm{dt}}=\mu \mathrm{X}-\mathrm{k}_{\mathrm{d}} \mathrm{X} \\
& \frac{\mathrm{dP}}{\mathrm{dt}}=\alpha \frac{\mathrm{dX}}{\mathrm{dt}}+\beta \mathrm{X} \\
& \mu=\mu_{\max } * \frac{\mathrm{s}}{\mathrm{K}_{\mathrm{S}}+\mathrm{S}+\frac{\mathrm{S}^{2}}{\mathrm{~K}_{\mathrm{I}}}} *\left(1-\left(\frac{\mathrm{P}}{\mathrm{Pm}}\right)^{\mathrm{n}}\right) * \exp \left(-\mathrm{K}_{\mathrm{AI}} * \mathrm{AcH}\right) * \exp \left(-\mathrm{K}_{\mathrm{FI}} * \mathrm{~F}\right)
\end{aligned}
$$

Where $\mathrm{S}$ is the concentration of glucose, xylose or a mixture of both. Finally continuous co-fermentation takes place in two CSTRs in series ${ }^{21}$ with a recycle ratio of four (Equations 8-10). Obviously the fermentation section will also affect the design of the purification zone. In our case the extractive distillation option (using ethylene-glycol as solvent) has been selected and utilises four distillation columns. Furthermore the bottom stream of the first distillation column is sent to a multi-effect evaporator unit to separate water from the other components (mainly unfermented sugars). This stream is mixed with lignin and residues of 
cellulose and hemicellulose and enters a steam cycle unit. Of the options, SScF achieves lower energy demands and lower costs for ethanol recovery. The techno-economic assessment suggests, as depicted in Table 4, that the most feasible pathway is SHcF. The main advantage of SHcF compared to SSF or SScF processes is that hydrolysis and fermentation take place at their own optimal conditions and with respect to SHF, there is increased productivity due to lower overall reactor volume.

$$
\begin{aligned}
& \mu_{\mathrm{X}_{\mathrm{L}}}=\mu_{\max }\left(\frac{\mathrm{S}_{\mathrm{i}}}{\mathrm{K}_{\mathrm{S}, \mathrm{X}}+\mathrm{S}_{\mathrm{i}}}\right)\left(1-\frac{\mathrm{P}_{\mathrm{i}}}{\mathrm{P}_{\mathrm{m}, \mathrm{X}}}\right)^{\mathrm{n}}\left(1-\frac{\mathrm{X}_{\mathrm{i}}}{\mathrm{X}_{\mathrm{m}}}\right) \\
& \mu_{\mathrm{P}_{\mathrm{t}}}=\mu_{\max }\left(\frac{\mathrm{S}_{\mathrm{i}}}{\mathrm{K}_{\mathrm{S}, \mathrm{P}}+\mathrm{S}_{\mathrm{i}}}\right)\left(1-\frac{\mathrm{P}_{\mathrm{i}}}{\mathrm{P}_{\mathrm{m}, \mathrm{P}}}\right) \\
& \mu_{\mathrm{S}_{\mathrm{\iota}}}=\frac{\mu_{\mathrm{X}_{\mathrm{i}}}}{\mathrm{Y}_{\mathrm{X} / \mathrm{S}}^{*}}+\frac{\mu_{\mathrm{P}_{\mathrm{i}}}}{\mathrm{Y}_{\mathrm{P} / \mathrm{S}}^{*}}+\mathrm{m}
\end{aligned}
$$

Table 4. Technical and financial data of fermentation alternatives

\begin{tabular}{lccccc}
\hline & SHF & SHcF & SSF & SScF & Continuous \\
\hline Time (or residence time) [h] & 100 & 90 & 80 & 75 & 15 \\
EtOH yield (including Cellulose hydrolysis) [\%] & 87 & 84 & 80 & 70 & 75 \\
Productivity [(g/(L×h)] & 1 & 1.05 & 1 & 0.95 & 1.22 \\
Production Cost [£/L of EtOH produced] & 0.36 & 0.35 & 0.37 & 0.38 & 0.38 \\
Heating duty (recovery section) [MW] & 41 & 32.5 & 30.5 & 29 & 30.5 \\
Cooling duty (recovery section) [MW] & 37 & 28.5 & 26.5 & 25.3 & 27.2 \\
Energy efficiency [\%] & 44 & 46.1 & 44 & 40 & 41.2 \\
Net Present Value (NPV) [£M] & 39.6 & 47.7 & 37.4 & 30.1 & 22 \\
\hline
\end{tabular}




\section{DISCUSSION}

In principle, the optimal pretreatment conditions in an SSF procedure are the same as those of an SHF procedure ${ }^{22}$. The main advantages of conducting the enzymatic hydrolysis in conjunction with the fermentation, rather than in a separate step after the hydrolysis are the reduced end-product inhibition of the enzymatic hydrolysis, and the reduced capital costs. The main disadvantages, on the contrary, are the necessity to determine conditions which favour both hydrolysis and fermentation (e.g. temperature and $\mathrm{pH}$ ) and the bottleneck to recycle the fermenting organism ${ }^{\mathbf{2 2}}$. These drawbacks highly affect the ethanol yields and in sequence the productivity and the production cost. $\mathrm{SS}(\mathrm{c}) \mathrm{F}$ processes can attain higher ethanol concentration with increased substrate loading. The best way to achieve this, is through stepwise addition of substrate and therefore operation at fed-batch mode ${ }^{\mathbf{2 3}}$. Furthermore recent studies have shown that $\mathrm{SScF}$ processes can perform well at low enzyme loading ${ }^{24}$ which will lead to significantly reduced production cost. However these technologies are yet to be established on a large scale and thereby at the current technological status $\mathrm{SH}(\mathrm{c}) \mathrm{F}$ processes are more profitable. Continuous fermentation can decrease the substrate and product inhibitory effects and along with the reduced working value results in high productivities $^{\mathbf{2 5}}$. The constraint of this approach is that the dilution rate cannot be greater than the specific growth rate thus the overall ethanol yield is lower compared to the other alternatives. Additionally, aeration is essential to maintain the cell viability but this increases the operating cost of the process and negatively affects the energy efficiency ${ }^{\mathbf{2 6}}$. Finally contamination is less likely to occur in SHF processes due to the fact that saccharification can operate under conditions that do not enhance contaminant growth and the shorter fermentation time with sugars and bacterial contaminants ${ }^{27}$. 
Nowadays, several studies focus on identifying the conditions that would improve the efficiency of SS(c)F processes. Most efforts concentrate on developing microorganisms that would increase ethanol productivity and reducing the enzyme loading ${ }^{22}$. Taking all the above comments into consideration we conducted a sensitivity analysis on the production cost of each alternative by varying the fermentation time, the ethanol yield and the enzymes loading. It was observed that for all processes the most sensitive design variable is the enzyme loading and that with certain advances the production cost of the $\mathrm{SS}(\mathrm{c}) \mathrm{F}$ procedures could decrease to $0.32 £ / L$ of ethanol produced (see Figure 2) and thereby it would be possible to outplay $\mathrm{SH}(\mathrm{c}) \mathrm{F}$ processes. Furthermore it is obvious that there is more room for optimization for the $\mathrm{SS}(\mathrm{C}) \mathrm{F}$ processes. 


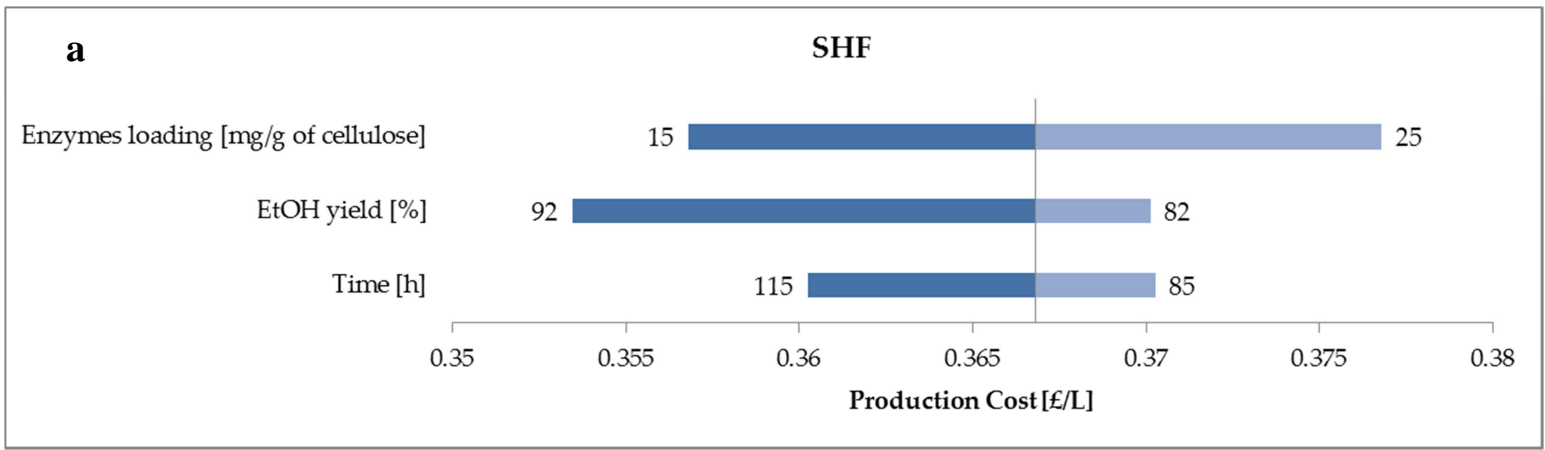

b

$\mathrm{SHcF}$

Enzymes loading [mg/g of cellulose]

EtOH yield [\%]

Time [h]

15

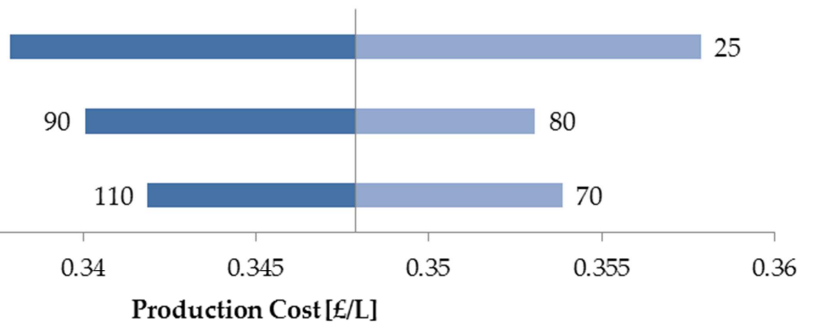

c

SSF

Enzymes loading [mg/g of cellulose]

10

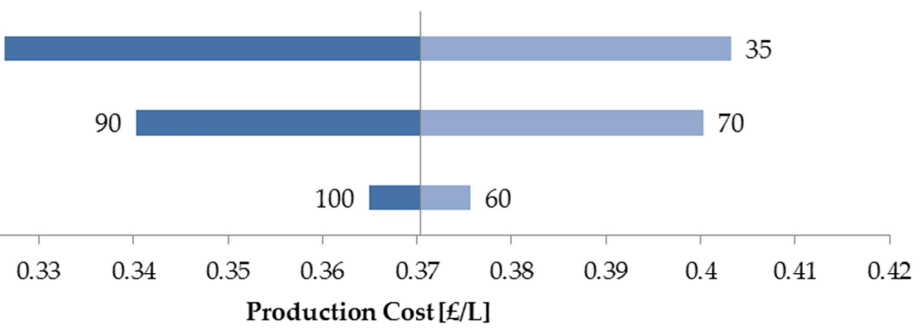

EtOH yield [\%]

Time [h]

$0.31 \quad 0.32$

0.335

Production $\operatorname{Cost}[t / L]$

d

Enzymes loading [mg/g of cellulose] EtOH yield [\%]

Time [h]

80

$\mathrm{SScF}$

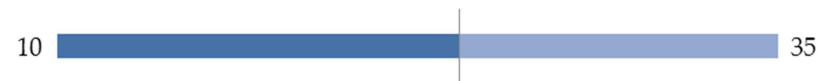

80

60

\begin{tabular}{|c|c|c|c|c|c|c|c|c|c|c|c|}
\hline 0.32 & 0.33 & 0.34 & 0.35 & 0.36 & 0.37 & 0.38 & 0.39 & 0.4 & 0.41 & 0.42 & 0.43 \\
\hline \multicolumn{12}{|c|}{ Production Cost $[E / L]$} \\
\hline
\end{tabular}

Figure 2. Sensitivity analysis on ethanol production cost for each alternative (a-SHF,

b-SHcF, c-SSF and d-SScF) 


\section{CONCLUSIONS}

The present research makes a consistent and comparative assessment of the overall thermochemical energy and economic efficiencies of potential bagasse-to-ethanol conversion options and based on this result, gives an endorsement as to which of the options assessed is

most desirable. So far, any comparative study conducted ${ }^{\mathbf{2 8 , 2 9 , 3 0}}$ would test alternatives at each stage of the process separately and not as an entirety. The comparison was performed based only on calculated technical data (e.g. cellulose conversion, ethanol productivity) without taking into consideration the energetic and the economic performance which after all count for the feasibility of a proposed process. In this study, kinetic models have been adopted from the literature and have been incorporated and integrated into process models. Mass and energy balance data were extracted, then, from the simulations and the overall yields and financial performance of each process were determined and compared. Dilute acid hydrolysis was selected as pretreatment method, on site production of enzymes was rejected and for the fermentation section $\mathrm{SHcF}$ is the preferred solution.

Figure 3 is a flow diagram for the proposed process. Raw bagasse is dried into a fluidized bed drier and then grinded up to a final particle size equal to $2 \mathrm{~mm}$. Treated bagasse is then mixed up with dilute sulphuric acid solution and enter a reactor vessel $\left(\mathrm{T}=112^{\circ} \mathrm{C}, \mathrm{P}=5 \mathrm{bar}\right.$ and $\mathrm{t}=30 \mathrm{~min}$ ) where the hemicellulose hydrolysis takes place. The solids are separated from the hemicellulose hydrolysates and enter the hydrolysis reactor along with enzymes. The cycle time of the process is equal to $50 \mathrm{~h}$. Hydrolysates are detoxified, produced gypsum is removed and the xylose rich stream is mixed with the glucose stream and enter the fermentation unit. The fermentation lasts $40 \mathrm{~h}$, at $32^{\circ} \mathrm{C}$ and the employed yeast is recombinant Saccharomyces $1400\left(\right.$ pLNH33 $^{\mathbf{1 9}}$. Ethanol is recovered via extractive distillation in a four stage process. 


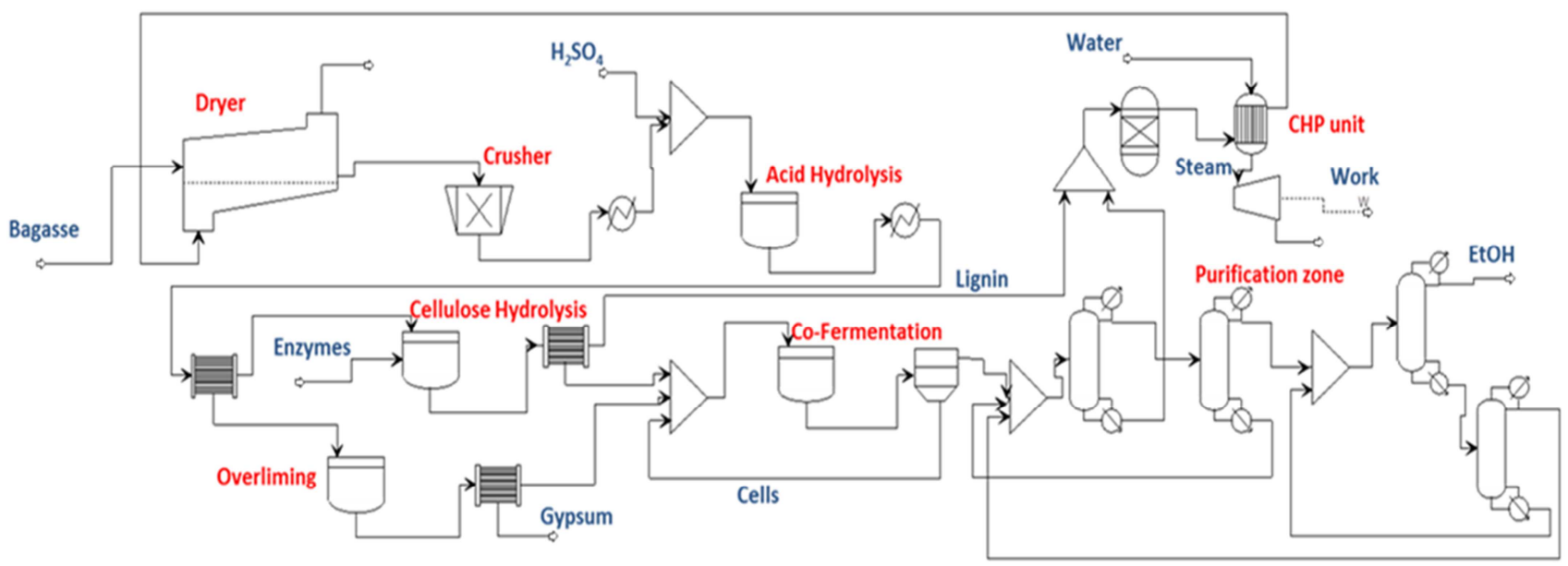

Figure 3. SHcF process schematic

\section{AUTHOR INFORMATION}

\section{Corresponding Author}

*E-mail: colin.webb@manchester.ac.uk

\section{Notes}

The authors declare no competing financial interest.

\section{NOMENCLATURE}

\section{Variables}

F furfural concentration $[\mathrm{g} / \mathrm{L}]$

$\mathrm{k}_{\mathrm{d}} \quad$ specific cell death rate $\left[\mathrm{h}^{-1}\right]$ 
$\mathrm{K}_{\mathrm{AI}} \quad$ acetic acid inhibition constant [L/g]

$\mathrm{K}_{\mathrm{FI}}$ furfural inhibition constant [L/g]

$\mathrm{K}_{\mathrm{I}} \quad$ substrate growth inhibition term $(\mathrm{g} / \mathrm{L})$

$\mathrm{K}_{\mathrm{S}} \quad$ saturation growth constant $[\mathrm{g} / \mathrm{L}]$

m maintenance parameter $[\mathrm{g} /(\mathrm{g} \times \mathrm{h})]$

$\mathrm{P} \quad$ product concentration $[\mathrm{g} / \mathrm{L}]$

$\mathrm{P}_{\mathrm{m}} \quad$ product concentration above which there is no growth $[\mathrm{g} / \mathrm{L}]$

$\mathrm{P}_{\mathrm{m}, \mathrm{P}} \quad$ ethanol concentration for $\mu_{\mathrm{P}}=0[\mathrm{~g} / \mathrm{L}]$

$\mathrm{P}_{\mathrm{m}, \mathrm{X}}$ ethanol concentration for $\mu_{\mathrm{X}}=0[\mathrm{~g} / \mathrm{L}]$

$\mathrm{r} \quad$ recycle ratio

S substrate concentration $[\mathrm{g} / \mathrm{L}]$

$\mathrm{Y}_{\mathrm{P} / \mathrm{S}} \quad$ product yield coefficient $[\mathrm{g} / \mathrm{g}]$

$\mathrm{Y}_{\mathrm{X} / \mathrm{S}} \quad$ biomass yield coefficient $[\mathrm{g} / \mathrm{g}]$

$\mathrm{X}$ biomass concentration $[\mathrm{g} / \mathrm{L}]$

\section{Greek symbols}

$\alpha \quad$ growth-related product formation coefficient $[\mathrm{g} / \mathrm{g}]$

$\beta \quad$ non-growth-related product formation coefficient $[\mathrm{g} /(\mathrm{g} \times \mathrm{h})]$

$\mu \quad$ specific growth rate $\left[\mathrm{h}^{-1}\right]$ 
$\mu_{\max } \quad$ maximum specific growth rate $\left[\mathrm{h}^{-1}\right]$

$\mu_{\mathrm{Pi}} \quad$ Specific rate of ethanol production in stage $\mathrm{i}[\mathrm{g} /(\mathrm{g} \times \mathrm{h})]$

$\mu_{\mathrm{Si}} \quad$ Specific rate of sugar consumption in stage $\mathrm{i}[\mathrm{g} /(\mathrm{g} \times \mathrm{h})]$

$\mu_{\mathrm{Xi}} \quad$ Specific growth rate in stage $\mathrm{i}[\mathrm{g} /(\mathrm{g} \times \mathrm{h})]$

\begin{abstract}
Abbreviations
ACC, Annualised capital cost; LHW, Liquid hot water; NPV, Net present value; $\mathrm{SH}(\mathrm{c}) \mathrm{F}$, Separate hydrolysis (co) fermentation; SS(c)F, Simultaneous saccharification and (co) fermentation;
\end{abstract}

\title{
REFERENCES
}

[1] Murphy, C. W.; Kendall A. Life cycle analysis of biochemical cellulosic ethanol under multiple scenarios. GCB Bioenergy. 2015, 7, 1019-1033.

[2] Chauhan, M.K.; Varun; Chaudhary, S.; Kumar, S.; Samar. Life cycle assessment of sugar industry: A review. Renewable and Sustainable Energy Reviews. 2011, 15, 3445-3453.

[3] Pandey, A.; Soccol, C.R.; Nigam, P.; Soccol, V.T. Biotechnological potential of agroindustrial residues. I: sugarcane bagasse. Bioresource Technology. 2000, 74, 69-80.

[4] Cardona, C.A.; Sánchez, Ó.J. Fuel ethanol production: process design trends and integration opportunities. Bioresource Technology. 2007, 98, 2415-2457.

[5] Maeda, R. N.; Serpa, V. I.; Rocha, V. A. L.; Mesquita, R. A. A.; Anna, L. M. M. S.; De Castro, A. M.; Driemeier, C. E.; Pereira JR, N.; Polikarpov, I. Enzymatic hydrolysis of 
pretreated sugar cane bagasse using Penicillium funiculosum and Trichoderma harzianum cellulases. Process Biochemistry. 2011, 46, 1196-1201.

[6] Cardona, C.A.; Quintero, J.A.; Paz, I.C. Production of bioethanol from sugarcane bagasse: Status and perspectives. Bioresource Technology. 2010, 101, 4754-4766.

[7] Rabelo S.C.; Vaz Rossell C.E.; de Moraes Rocha G.J.; Zacchi G. Enhancement of the enzymatic digestibility of sugarcane bagasse by steam pretreatment impregnated with hydrogen peroxide. Biotechnology Progress. 2012, 28, 1207-1217.

[8] Diedericks D.; van Rensburg E.; Garcia-Aparicio Mdel P.; Gorgens J.F. Enhancing the enzymatic digestibility of sugarcane bagasse through the application of an ionic liquid in combination with an acid catalyst. Biotechnology Progress. 2012, 28, 76-84.

[9] Aguilar, R.; Ramírez, J.A. ; Garrote, G.; Vazquez, M. Kinetic study of the acid hydrolysis of sugar cane bagasse. Journal of Food Engineering. 2002, 55, 309-318.

[10] Shao, X. ; Lynd, L. Kinetic modeling of xylan hydrolysis in co- and countercurrent liquid hot water flow-through pretreatments. Bioresoure Technology. 2013, 130, 117-124.

[11] Sun, Y.; Cheng, J. Hydrolysis of lignocellulosic materials for ethanol production: a review. Bioresource Technology. 2002, 83, 1-11.

[12] Wooley, R.; Putsche, V. Development of an ASPEN PLUS Physical Property Database for Biofuels Components. NREL/MP-425-20685. 1996.

[13] Peri, S.; Karra, S.; Lee, Y.Y.; Karim, M.N. Modeling Intrinsic Kinetics of Enzymatic Cellulose Hydrolysis. Biotechnology Progress. 2007, 23, 626-637.

[14] Benoliel, B.; Torres, F. A. G.; de Moraes, L. M. P. A novel promising Trichoderma harzianum strain for the production of a cellulolytic complex using sugarcane bagasse in natura. SpringerPlus. 2013, 2:656. 
[15] Pirota, R. D. P. B.; Baleeiro, F. C. F.; Farinas, C. S. Saccharification of biomass using whole solid-state fermentation medium to avoid additional separation steps. Biotechnology Progress. 2013, 29, 1430-1440.

[16] Davis, R.; Tao, L.; Tan, E.C.D.; Biddy, M.J.; Beckham, G.T.; Scarlata, C.; Jacobson, J.;

Cafferty, K.; Ross, J.; Lukas, J.: Knorr, D.; Schoen, P. Process Design and Economics for the Conversion of Lignocellulosic Biomass to Hydrocarbons: Dilute-Acid and Enzymatic Deconstruction of Biomass to Sugars and Biological Conversion of Sugars to Hydrocarbons. NREL-TP-5100-60223. 2013.

[17] Klein-Marcuschamer, D.; Oleskowicz-Popiel, P.; Simmons, B.A.; Blanch, H.W. The challenge of enzyme cost in the production of lignocellulosic biofuels. Biotechnology and Bioengineering. 2012, 109, 1083-1087.

[18] Li, X.; Yi, J.-p.; Ren, Y.-1.; Yin, W.-p. Modeling alcoholic fermentation of glucose/xylose mixtures by ethanologenic Escherichia coli as a function of $\mathrm{pH}$. Annals Microbiology. 2014, 64, 459-473.

[19] Krishnan, M.S.; Ho N.W.Y.; Tsao G.T. Fermentation kinetics of ethanol production from glucose and xylose by recombinant Saccharomyces 1400(pLNH33). Applied Biochemistry and Biotechnology. 1999, 78, 373-388.

[20] Qureshi, N.; Dien, B.S.; Nichols, N.N.; Saha, B.C.; Cotta, M.A. Genetically Engineered Escherichia Coli for Ethanol Production from Xylose: Substrate and Product Inhibition and Kinetic Parameters. Food and Bioproducts Processing. 2006, 84, 114-122.

[21] de Oliveira, S.; de Castro, H.; Visconti, A.; Giudici, R. Mathematical modeling of a continuous alcoholic fermentation process in a two-stage tower reactor cascade with flocculating yeast recycle. Bioprocess Biosystem Engineering. 2015, 38, 469-479. 
[22] Olofsson, K.; Bertilsson, M.; Lidén, G. A short review on SSF - an interesting process option for ethanol production from lignocellulosic feedstocks. Biotechnology for Biofuels. 2008, 1: 7.

[23] Taherzadeh M.J.; Niklasson C.; Liden G. Conversion of dilute-acid hydrolyzates of spruce and birch to ethanol by fed-batch fermentation. Bioresoure Technology. 1999, 69, 5966.

[24] Sassner P.; Galbe M.; Zacchi G. Bioethanol production based on simultaneous saccharification and fermentation of steam pretreated Salix at high dry-matter content. Enzyme and Microbial Technology. 2006, 39, 756-762.

[25] Brethauer S.; Wyman C.E. Review: Continuous hydrolysis and fermentation for cellulosic ethanol production. Bioresource Technology. 2010, 101, 4862-4874.

[26] Kida K.; Yamadaki M.; Asano S-I; Nakata T.; Sonoda Y. The effect of aeration on stability of continuous ethanol fermentation by flocculating yeast. Journal of Fermentation and Bioengineering. 1989, 68, 107-111.

[27] Beckner M.; Ivey M.L.; Phister T.G. Microbial contamination of fuel ethanol fermentations. Letters in Applied Microbiology. 2011, 53, 387-394.

[28] Conde-Mejía C, Jiménez-Gutiérrez A, El-Halwagi M. A comparison of pretreatment methods for bioethanol production from lignocellulosic materials. Process Safety and Environmental Protection. 2012;90(3):189-202.

[29] Dahnum D.; Tasum S.O.; Triwahyuni E.; Nurdin M.; Abimanyu H. Comparison of SHF and SSF Processes Using Enzyme and Dry Yeast for Optimization of Bioethanol Production from Empty Fruit Bunch. Energy Procedia. 2015, 68, 107-116. 
[30] Öhgren K.; Bura R.; Lesnicki G.; Saddler J.; Zacchi G. A comparison between simultaneous saccharification and fermentation and separate hydrolysis and fermentation using steam-pretreated corn stover. Process Biochemistry. 2007, 42, 834-839. 